\section{DE DE GRUYTER} OPEN
Przedsiębiorczość i Zarządzanie Entrepreneurship and Management University od Social Sciences Publishing House ISSN 1733-2486

Volume XVI, Issue 2, pp. 77-88

DOI 10.1515/eam-2015-0018

Joanna Kijewska

Poznań University of Technology

Witold Nowak

Adam Mickiewicz University in Poznań

\title{
Informative Aspects of Innovation Implementation within Organisations
}

\begin{abstract}
The aim of this paper is to analyse the informative aspects of implementing innovations within contemporary formal organisations, in particular, in enterprises. The paper concerns the information quality and its influence on the process of innovation implementation. Today, in conditions of the dynamic development of the scientific and technological knowledge, the question is no longer if there is a need to imply innovation but how to do it efficiently. Within the process of innovation implementation, the organisation's management selects the appropriate ideas, makes the decision and takes the action to implement a new or a significantly improved solution. In this paper, the factors interrelated with the process of innovation implementation were analysed. The information asserts itself as a significant factor which influences the process. The neoinstitutional view on the information in organisations was a starting point for analysis. A conceptual framework of the information attributes, which influence the quality of the implementation of an innovation, was proposed. The applied research method is the secondary data analysis, which was based on the theoretical literature, as well as the empirical research results.
\end{abstract}

Key words: innovation, information quality, new institutionalism. 


\section{Introduction}

The innovation, in the Oslo Manual [OECD and Eurostat, 2005, p. 46] is defined as the implementation of a new or significantly improved product (good or service), or process, a new marketing method, or a new organisational method in business practices, workplace organisation or external relations. The process of innovation implementation encompasses all scientific, technological, organisational, financial and commercial steps which lead to the usability of implemented innovations within organization. Cruz-Cázaresa et al. [2013, p. 1239] stress the idea that the innovation inputs produce innovation outputs, through a complex process. Therefore, the key to increasing firm performance and competitiveness is to focus on the undertaken process's efficiency.

Although there are various approaches to the innovation, the innovation's local character is its defining characteristic. This means, that even if other organisation has already applied a specific product, process and method, when that product, process or method is being applied to the particular organisation, it is an innovation in it [Cempel 2013, p.27]. It also may be stated that every innovation implementation is unique.

Analysis of the innovation concepts from an informative perspective attempts to consider the information as one of the inherent aspects of the innovations initiatives. The information aspect is assumed here as the one, which influences the innovation initiatives, and further determines the competitive strength of the organisation (particularly enterprises).

The aim of the paper is to discuss the informative aspects of implementing innovations within contemporary formal organisations, in particular, within enterprises. The paper first analyses, on the basis of the neo-institutional approach, stages of the process of innovation implementation when the information quality is essential. Then, the notion of the quality is set beside the information. Finally, on the basis of the literature review, the required information's attributes are listed.

\section{Neo-institutional view on the information in organisations}

The role of information during the innovation implementation process may be analysed from two basic perspectives: the decision-making leading to initiation of the particular solution introduction and the course of the implementation itself. The former, as will be proven, is above all a matter of the organisation's decision-makers relations with a particular organisational field and the information flow on that level, the latter, seems to be much more a matter of intraorganisational processes and staff relations. The main theoretical framework of 
the presented considerations is constituted on the basis of concepts presenting the New-Institutional Economics perspective.

The P.S. Tolbert's and L.G. Zucker's concept of (micro)institutionalisation seems to be particularly relevant to highlight the importance of the information flow between the organisation's decision-makers and organisational field in innovative processes. Above-mentioned authors present a view of institutionalization of structural arrangements in organizational fields - as defined by P.J. DiMaggio and W.W. Powell [1983, p. 147]. The institutionalization process can be divided into three fundamental phases following appearance of innovation in organizational field: habitualization, objectification and sedimentation (Figure 1) [Tolbert 1996, pp. 175-190].

\section{Figure 1. Processes of institutionalization}

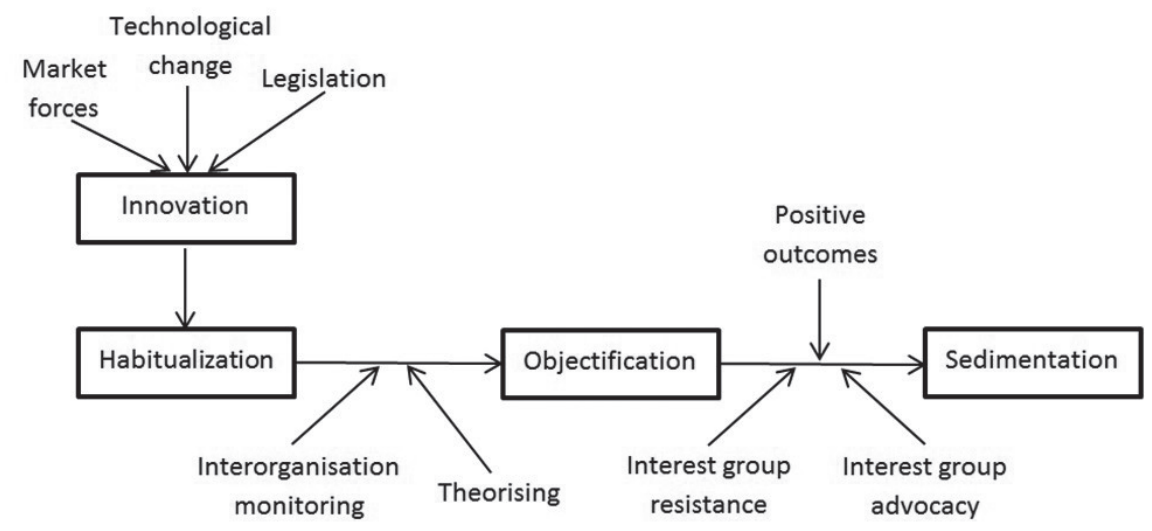

Source: Tolbert, P. S., Zucker, L. G., The institutionalization of institutional theory [in:] S. Clegg, C. Hardy and W. Nord (Eds.), Handbook of organization studies, 1996, p. 182.

The first of above-mentioned stages - process of habitualization, is initiated when, as a result of a specific organizational problem or set of problems, new structural arrangements appear. Further, the structural arrangements are being formalized in the policies, strategies and procedures of a particular organization (or various organizations facing similar challenges). Such formalization results in a so-called pre-institutionalization of structures - their creation in organizations is rather an independent activity, even if happens simultaneously. It may be explained by the influence of decision-makers' common core of knowledge (e.g. gained in the standardized educational processes) and diffusion of particular ideas making an innovation attractive in management professional environments. Even though imitation may be observed, it is not 
caused by a sense of the necessity of a particular structural arrangement application among organisational decision-makers since the utility of the innovation has not been proved and accepted yet [Tolbert 1996, pp. 175-190]. Referring to the main topic of the article, it may be noticed that at that stage the flow of information from the organizational field is not essential for the decision-making process in the organization. Established external social norms concerning particular problem solution do not exist and managers make relatively independent decisions basing mostly on the current intra-organisational information.

When the structure is diffused and gains a more permanent and widespread status, it indicates that the next process - objectification, is ongoing. In that phase some degree of social consensus among organisational decisionmakers concerning the value of a structural arrangement appears, that results in its increasing popularity. The process of consensus emergence may be driven through two different (and sometimes interrelated) mechanisms. Firstly, organisational decision-makers during the new structure risk assessment may take into consideration information on the choices in other organisations. In other words objectification of a structural arrangement is in some degree an outcome of a competitive game. Such phenomenon may be also treated as a cost optimization strategy, because adoption of 'pre-tested' solution involves fewer resources than creating new structural arrangements. Thus, as a particular choice becomes more popular, the influence of individual, independent assessments is decreasing and the role of information flow from the organisational field in decisions on innovation implementation is increasing. Secondly, objectification process may be driven by other significant social actors - socalled 'champions' - sets of individuals having a material stake in the diffusion of the structure. Such group is likely to appear when numerous potential 'consumer' of the innovation exist (number of organizations face a similar functioning problems). Champion's success depends on their capacity to effectively conduct the theorization process in three essential aspects: creation of an organisational problem definition, presentation of a particular innovation as a solution to the defined problem and providing positive perception of a structure as their effective solution [Tolbert 1996, pp. 175-190].

Structural arrangement is fully institutionalized as a result of sedimentation - phase characterized with continuity of structure existence in organizations' functioning regardless of organizational members' generational changes and prevalence among organisational actors identified during theorization. However, promotion by champions and positive perception of desired outcomes in organisational fields are in some cases not sufficient enough for a structure 
to attain full institutionalization. They have to be accompanied with relatively low resistance by opposing (particularly intraorganisational) groups or effectively counteract their entropic tendencies to provide a widespread adoption of an innovation among organisational relevant adopters [Tolbert 1996, pp. 175-190].

New institutionalism offers also another insight into the significance of information in the innovation processes. Namely, application of the information asymmetry concept demonstrates how unequal distribution of information and its quality may influence the implementation of new solutions. Eric von Hippel's analysis proves how information asymmetry on the market determines the innovation activities and their profile. It is particularly clearly visible in a comparison of product and service development processes that proves a tendency of users and manufacturers to develop different types of innovations. Information asymmetries between those two basic categories result from the fact that users generate need and context-of-use information, while manufacturers specialized in a particular type of solution create generic solution information. These both categories of information (need and solution) are often costly to transfer (so-called 'sticky' information), what results in users' more accurate and more detailed view of their own needs and manufacturers' better model of the solution approach. Such information asymmetry entails that 'users tend to develop innovations that are functionally novel, requiring a great deal of user-need information and use-context information for their development', while 'manufacturers tend to develop innovations that are improvements on well-known needs and that require a rich understanding of solution information for their development' [Von Hippel 2005].

The second mentioned issue - significance of information quality for the innovation implementation from the intra-organisational perspective, seems to be rather unrecognized. The available literature on the link between information quality and employees' attitudes towards organizational change (innovation implementation certainly should be treated as such) is rather limited. More attention is paid to the role of communication process characteristics in general, but it is rather rarely analysed from the perspective of its quality [Wyer, Albarracin 2005, p. 297]. However, the information quality may be treated as one of the general communication process's aspects. According to Wim Elving, an essential role of change communication is to inform the members of organization about the particular change initiative (in the analysed context caused by innovation implementation) and its influence on their situation. However, a fundamental distinction on communication as a mean to provide information and to create a community spirit has to be underlined 
(as illustrated on the Figure 2) [Elving 2005, pp. 130-131]. Obviously both aspects of organizational communication are interdependent and from the presented article's perspective it is hard to decide which function seems to be more significant. Both - the informative and communitarian function of communication may be described as having an effect on employees' readiness for change (planned innovation initiative) as Figure 2 suggests. Thus information asymmetry between different positions in organizational structure seems to condition the course of innovation implementation, because of its influence on employees' attitudes toward particular initiative and social processes that it releases. Most of the attention in organizational change literature is drawn to the importance of information transfer from management staff to rank and file workers. However, analysing the influence of information quality on innovation implementation seems to require putting it the opposite way as well. The flow of information from individual employees operationally implementing the innovation to the management staff seems as relevant to its success as the influence of information transferred top-down.

\section{Figure 2. The transmission of information about the object's features in the communication process}

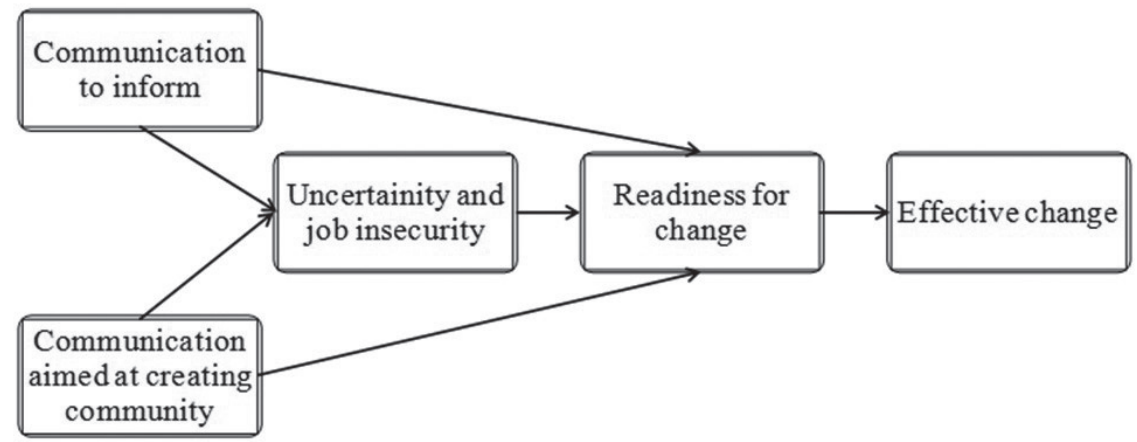

Source: Elving W.J.L., The role of communication in organisational change, "Corporate Communications: An International Journal”, Vol. 10 Iss: 2/2005, pp. 129-138.

However, taking the postmodernist view on organizational theory and management, possible resistance, ambivalence or unpredicted reaction of employees towards innovations implemented in organizations are ordinary, and repeatedly desired phenomena. It is obviously contrasting with a view that dominates the managerial mainstream in organizational studies. The latter is associated with an assumption that resistance to change is a negative phenomenon because it reduces its initial energy - moderates and weakens organiza- 
tional change propagation [Czarniawska 2010, pp. 162-163]. In the article topic's context it leads to an unexpected conclusion - information quality loss does not have to be perceived as a negative or harmful phenomenon during innovation processes (or organizational changes in general), if it is taken into consideration by innovation agents. In some circumstances "translation" of the distributed information may even create added value. The conducted analysis indicates that the information issues should be incorporated into the research of the innovation implementation. The information importance in the institutionalization processes was highlighted. The information was also analysed in the terms of the innovation and diffusion phenomena. The information asymmetry among the market participants and within organization was taken into consideration. Although, the information is considered as an important factor, the researches which indicate directly what characteristics of information lead to the improvement of the innovation implementation are rather rare. The information quality is commonly assumed as the information which leads to the appropriate decisions in the implementation process and that quality, according to the conducted analysis, is rather unrecognized. Therefore, the further considerations in the paper focus on the category of information quality in terms of the innovation initiatives.

\section{The conceptual framework of information quality}

Based on Kolman [2009, pp. 57-59] approach to the category of quality it is an abstractive notion and is not measurable ${ }^{1}$. Since, there is no well-established physical unit, which defines the quality in a universal way, and that precludes from measuring the quality. Following Kolman's [2009] concept, the quality is analysed by the degree to which the real object satisfies the requirements as defined for that object. Mantura [2012, p. 14] states that 'the quality is the set of attributes and the quality of an object is a set of attributes belonging to it'. Therefore, it is assumed here that, for the specific tasks the specified states of objects attributes are required. The object which is considered in the paper is an information. An information quality is analysed by, firstly, defining the set of attributes which belong to it, and secondly, by identifying which states of each attributes need to be achieved in terms of the beforehand specified requirements. It is indicated that there is a diversity and incoherence of presented ideas of the notion of information, including different approaches to terminology. Some authors treat information as an original term (undefined)

1 In the metrology, the measurement is the comparison of two objects in which the one unit is the module unit [Kolman 2009]. 
whereas other authors formulate definitions, which vary significantly' [Mantura 2010, pp. 47-49]. The notion of information is defined as 'the products of human thought operating in minds which reflect reality and create immaterial reality' [Mantura 2012, p. 21]. Through information the empirical system and its objects are recognized and the observer's individual abstract system is created. The ratio of similarity, between the real system and the abstract system indicates the information quality [Kijewska, Nowak 2014, pp. 109-126]. The information attributes which lead to the increase of the ratio of similarity, between the real system and the conceptual construction of realty, are of central importance.

Thus, in order to reflect the reality precisely, the organization members, particularly management staff, need to select the appropriate information. According to the recognized input information the organizational actors select the appropriative ideas, make the decision and take action to implement the innovation, the new or significantly improved solution. The information quality also influences the implementation process within the organization's internal environment. In the next chapter, based on the literature review, requirements for the information attributes were listed in terms of the process of innovation implementation.

\section{The requirements for information in the process of innovation implemen- tation}

In order to single out the requirements for the information attributes, a secondary data analysis was carried out, and as a result, following five general requirements are proposed.

The information characteristics influence the decision process. Decision making is a complex process consisting of evaluation, comparison and the final choice [Myšičková et al. 2011, p. 15]. Because people lack the full understanding of complex social systems and the human environment, they economize on brainpower by relying on incomplete models or theories [Eggertsson 2013, p. 3]. The incomplete information and the insufficient information quality have the effect of the decision-making process under the uncertainty and risk. Therefore, it is required that the information attributes and its state decrease the uncertainty and reduces the risk during a certain decision process.

Furthermore, as Mantura [2012, p. 24] noticed, 'the one of the most important interpersonal and social relations (much evidence indicates that this is the most important relation) is the communication and related to it the term "message". Following Mantura's definitions, 'the communication is the exchange of information between entities and a message is a coherent piece 
of information transferred between entities'. By the communication process, the input message (the source, coherent piece of information) is transferred by the communication channel to the output message (the received message). The similarity between the input message and the output message lead to the requirement that the information attributes and its states prevent form the information loss and assure the resistance to the information noise.

Economic decision making is usually described as a form of value-based decision making, in which individuals are assumed to first evaluate the different choice alternatives, and then compare the different values, and finally choose the one with the highest value [Myšičková et al. 2011, p. 2]. The issue of the decision making process is incorporated into various economic theories. Following Schlüter [2007, pp. 1092-1093] analysis, 'the New Institutional Economy (NIE) assumes actors that have bounded rationality. Neoclassical economics, from which NIE has partly developed, assumes rational actors. That means, actors taking economic decisions know about the costs and benefits associated with different choices and they choose what would, "objectively", be in their best interest, therefore maximizing their own benefit. But when actors take decisions within information constraints, they might take "wrong" decisions [Schlüter 2007, pp. 1092-1093]. Therefore, it is required that the information attributes and its states provide the message which increases rationality of the decision, or reduces the bounded rationality in the decision processes.

Following Loikkanen et al. [2009, p. 35], different information and a number of information sources are needed in different phases of the innovation process. The challenge to acquire information is constantly growing and an enterprise's competitive success critically depends on its ability to monitor and quickly seize external sources of information. Not only there is a mobility of information increase but also there is a quantity of information growth. Therefore, an organization's competitive success depends also on its ability to select the information, which is then processed within organization and transformed into knowledge. There is a high reach of the available information, and the cost of its communication falls, but the individual's abilities to process the information significantly differ. Kowalczyk [1981, p. 25] indicated, that there is a correlation between the information and the individual's capabilities and awareness. There is no information without the appropriate receiver. The individual's capabilities influence the processing of information, and it is required that the information attributes and its states facilitate the real-time processing personalized to the individual's capabilities and the environment's conditions. 
The last but not least requirement for information incorporates the cost of information. The costs of acquisition of information and its processing need to be considered in relation to the profit which the organization gains from the information, especially when the cost of information ranges from free of charge to extremely expensive.

Based on the analysis of the literature the requirements for the information quality were listed in terms of its conformance to the innovation implementation process. The given requirements indicate attributes of the information that are analysed in the process of the innovation implementation. The further researches, which is stated here, need to be conducted to precise the list of information attributes and define its appropriative states for the specified innovation process.

\section{Conclusions}

The aim of the presented paper was to analyse the importance of innovation implementation informative aspects within contemporary formal organizations, with particular attention put on enterprises. The presented theoretical background drawn from the neo-institutional perspective enabled to point the fields (or phases) of innovation implementation that seem to be particularly dependent on information quality transmitted from organization's external environment and within the organization itself. The dynamic environment forces contemporary organizations not only to initiate the process of the innovation implementation but also consider the information quality within the process. The analysis of the processes of institutionalization, the innovation diffusion phenomena and the information asymmetry indicated the information quality substance in the innovation implementation process and, in that, in the organizations competitiveness. The information quality was defined by the set of attributes of the information. The requirements for the information quality in terms of the innovation process were listed out. The presented directives related to the information quality role in innovative processes require empirical verification in further research phases.

\section{References}

Baskerville R.L., Myers M.D. (2009), Fashion waves in information systems research and practice, „MIS Quarterly”, 33.4, pp. 647-662.

Burke W.W., Lake D.G., Paine J.W. (Eds.) (2008), Organization change: A comprehensive reader, (Vol. 155), Wiley. Com. 
Cempel C. (2013), Inżynieria kreatywności w projektowaniu innowacji, Wydawnictwo Naukowe Instytutu Technologii Eksploatacji - PIB, Radom-Poznań.

Cruz-Cázaresa C., Bayona-Sáezb C., García-Marcob T. (2013), You can't manage right what you can't measure well: Technological innovation efficiency, „Research Policy", Volume 42, Issues 6-7, July-August.

Czarniawska B. (2010), Troche inna teoria organizacji: Organizowanie jako konstrukcja sieci dziatań, Wydawnictwo Poltext, Warszawa.

DiMaggio P.J., Powell W.W. (1983), The Iron Cage Revisited. Institutional Isomorphism and Collective Rationality in Organizational Fields, „American Sociological Review", 48.

Eggertsson T. (2013), Quick guide to New Institutional Economics, „Journal of Comparative Economics", 41.

Elving W.J.L. (2005), The role of communication in organisational change, „Corporate Communications: An International Journal”, Vol. 10, Iss: 2, pp.129-138.

Kijewska J., Nowak W. (2014), Employee Attitudes Towards Organizational Change in Relation to Enterprise Competitiveness. Remarks on the Role of Information Quality, „Oeconomia Copernicana”, Volume 5, Issue 3, pp. 109-126.

Kolman R. (2009), Kwalitologia. Wiedza o różnych dziedzinach jakości, Wydawnictwo Placet, Warszawa.

Kowalczyk E. (1981), O istocie informacji, Wydawnictwo Komunikacji i Łączności, Warszawa.

Loikkanen T., Konttinen J., Hyvönen J., Ruotsalainen L., Tuominen K., Waris M., Hyttinen V., Ilmarinen O. (2009), Acquisition, Utilisation and the Impact of Patent and Market Information on Innovation Activities [in:] VTT Tiedotteita Research Notes 2484, Es-poo.

Mantura W. (2010), Zarys kwalitologii, Wydawnictwo Politechniki Poznańskiej, Poznań.

Myšičková A., Song S., Majer P., Mohr P.N.C., Heekeren H.R., Härdle W. K. (2011), Risk Patterns and Correlated Brain Activities. Multidimensional statistical analysis of fMRI data with application to risk patterns [in:] SFB 649 Discussion Paper 2011-085.

Schlüter A. (2007), Institutional change in the forestry sector - The explanatory potential of New Institutional Economics, „Forest Policy and Economics”, 9.

Sienkiewicz P. (1987), Cybernetyka: teoria efektywności systemów, Ossolineum, Warszawa. 
The report: A new ranking of the world's most innovative countries: Notes on methodology, An Economist Intelligence Unit report sponsored by Cisco Limited 2009. Tolbert P.S., Zucker L.G. (1996), The institutionalization of institutional theory [in:] S. Clegg, C. Hardy, W. Nord (Eds.), Handbook of organization studies, London: SAGE.

Von Hippel E. (2005), Democratizing Innovation, MIT Press, Cambridge, London.

Wyer R.S., Albarracin D. (2005), Belief Formation, Organization and Change: Cognitive and Motivational Influences [in:] D. Albarracin, B.T. Johnson, M.P. Zanna (eds.), The handbook of Attitudes, Lawrence Erlbaum Associates Publisher, Mahwah, New Jersey - London.

Zacher L.W. (2007), Transformacje spoteczeństw: od informacji do wiedzy, C.H. Beck, Warszawa.

Zizlavsky O. (2012), The Development and Implementation of Marketing Information Sys-tem Within Innovation: The Increasing of Innovative Performance [in:] T. Burger-Helmchen (ed.), Entrepreneurship - Creativity and Innovative Business Models, InTech. 